\title{
Nutrient stock in the forest component in a crop-livestock-forest integration system in Central Brazil
}

Integrated systems are sustainable alternatives, where agricultural, forestry, and/or livestock components occupy a given area through consortium, rotation, or succession. Considering this importance, this work had as objective to quantify the stock of above-ground biomass (wood, leaves, bark, and branches) of 6 years Eucalyptus urograndis in a crop-livestock-forest integration system (CLFS). It also involved calculation of the nutrient utilization in biomass conversion through the Biological Utilization Coefficient (BUC) and design of different export scenarios of these nutrients through the harvest in order to calculate the reduction in the demand for inputs. Nutrient stock was determined from the biomass sampled in the field and from the plant tissue analysis. It is verified that the highest concentrations of macronutrients are present in wood component, except for $\mathrm{Ca}$. The concentration gradient of micronutrients was: Leaves $>\mathrm{Fe}>\mathrm{Mn}>\mathrm{B}>\mathrm{Cu}>\mathrm{Zn}$; Branches and Bark: $\mathrm{Fe}>\mathrm{Mn}>\mathrm{B}>\mathrm{Zn}>\mathrm{Cu}$; and wood: $\mathrm{Mn}>\mathrm{Fe}>\mathrm{Zn}>\mathrm{Cu}>\mathrm{B}$. Considering BUC conversion rate decline, it presented the following order: $\mathrm{S}>\mathrm{P}>\mathrm{Mg}>$ $\mathrm{Ca}>\mathrm{N}>\mathrm{K}$ for macronutrients and $\mathrm{B}>\mathrm{Cu}>\mathrm{Zn}>\mathrm{Fe}>\mathrm{Mn}$ for micronutrients. The most appropriate export scenario was to harvest only timber component to minimize the nutritional export. The nutritional dynamics within the eucalyptus are altered according to the diametric structure of the trees. The nutritional elements are concentrated in different compartments according to the availability and need of the plants.

Keywords: Forestry; Coefficient of biological use; Biomass; Exports nutrition

\section{Estoque de nutrientes no componente florestal em um sistema de integração lavoura-pecuária-floresta no Brasil Central}

Os sistemas integrados são alternativas sustentáveis, onde componentes agrícolas, florestais e/ou pecuários ocupam uma determinada área por meio de consórcio rotação ou sucessão. Considerando essa importância, este trabalho teve como objetivo quantificar o estoque de biomassa acima do solo (madeira, folhas, cascas e galhos) de Eucalyptus urograndis 6 anos em um sistema de integração lavoura-pecuária-floresta (CLFS). Também envolveu o cálculo da utilização de nutrientes na conversão da biomassa por meio do Coeficiente de Utilização Biológica (BUC) e o desenho de diferentes cenários de exportação desses nutrientes até a colheita para calcular a redução na demanda por insumos. O estoque de nutrientes foi determinado a partir da biomassa amostrada no campo e da análise do tecido vegetal. Verifica-se que as maiores concentrações de macronutrientes estão presentes no componente madeira, com exceção do Ca. $O$ gradiente de concentração dos micronutrientes foi: Folhas $>\mathrm{Fe}>\mathrm{Mn}>\mathrm{B}>\mathrm{Cu}>\mathrm{Zn}$; Ramos e Cascas: $\mathrm{Fe}>\mathrm{Mn}>\mathrm{B}>\mathrm{Zn}>\mathrm{Cu}$; e madeira: $\mathrm{Mn}>\mathrm{Fe}>\mathrm{Zn}>\mathrm{Cu}>\mathrm{B}$. Considerando o declínio da taxa de conversão BUC, apresentou a seguinte ordem: $\mathrm{S}>\mathrm{P}>\mathrm{Mg}>\mathrm{Ca}>\mathrm{N}>\mathrm{K}$ para macronutrientes e $\mathrm{B}>\mathrm{Cu}>\mathrm{Zn}>\mathrm{Fe}>\mathrm{Mn}$ para micronutrientes . $\mathrm{O}$ cenário de exportação mais adequado era colher apenas o componente de madeira para minimizar a exportação nutricional. A dinâmica nutricional dentro do eucalipto é alterada de acordo com a estrutura diamétrica das árvores. Os elementos nutricionais estão concentrados em diferentes compartimentos de acordo com a disponibilidade e necessidade das plantas.

Palavras-chave: Silvicultura; Coeficiente de uso biológico; Biomassa; Exportação de nutrição.

Topic: Ciências Florestais

Reviewed anonymously in the process of blind peer.

Jorge Luís Sousa Ferreira (id

Universidade Federal de Goiás, Brasil

http://lattes.cnpq.br/1438796673081557

http://orcid.org/0000-0003-1172-0807

jorgeluisferreira89@hotmail.com

Francine Neves Calil (iD

Universidade Federal de Goiás, Brasil

http://lattes.cnpq.br/2520537051838618

http://orcid.org/0000-0003-2882-9622

fncalil@gmail.com

Carlos de Melo e Silva Neto (ic

Instituto Federal de Goiás, Brasil

http://lattes.cnpq.br/2681735180356106

http://orcid.org/0000-0001-8624-3836

carloskoa@gmail.com
Received: 03/02/2021

Approved: 27/02/2021
Referencing this:

FERREIRA, J. L. S.; CALIL, F. N.; SILVA NETO, C. M.. Nutrient stock in the forest component in a crop-livestock-forest integration system in Central Brazil. Revista Ibero Americana de Ciências Ambientais, v.12, n.2, p.86-97, 2021. DOI: http://doi.org/10.6008/CBPC21796858.2021.002.0010 


\section{INTRODUCTION}

The genus Eucalyptus sp. was introduced in Brazil more than 150 years ago. The planting of this species today covers an area of 5.63 million Hectares, and production exceeds $36 \mathrm{~m}^{3} \mathrm{ha}^{-1}$ year $^{-1}$. Short-cycle seedlings are used for cellulose (6 - 7 years), and plantations with longer cycles are used for solid wood (around 12 years). The main products obtained with the species are cellulose, paper, wood panels, laminate floors, plywood panels, furniture, other solid wood products, coal, and biomass for energy production (IBA, 2016).

According to Vogel et al. (2013) and Vieira et al. (2013), the production of eucalyptus biomass can vary from ecosystem to ecosystem, as well as within the same ecosystem because of differences in the physical and chemical characteristics of the soils that influence the productivity of the stands. In addition, nutrient availability is one of the main factors for plant growth, although there is not always good correlation between soil contents and the amount absorbed by the plant.

Defining the amount of nutrients to be applied can be performed by different methods. A critical point in the definition of fertilization is the quantification of the nutrients that are exported from the site by the harvest because, in order to maintain a sustainable system, the exported nutrient should be restored (LAFETÁ et al., 2018). In addition, nutrient exports from these areas by means of this harvesting practice is determined by the amount of biomass exported from the site and by the concentration of nutrients in those tissues (GONÇALVES et al., 2015).

One of the methods to verify the efficiency of nutrient export by the crop and the use of these nutrients by the plant is the biological utilization coefficient (BUC), which is a tool to quantify this interaction of factors. This allows for making conclusions about the impact of the harvest on the nutrient exports, since it reflects the relation between the production of stem biomass and the content of a certain nutrient stored in this compartment.

Therefore, the objective of this study was to quantify the nutrient stock (macros and micronutrients) present in above-ground biomass (wood, leaves, bark, and twigs) in Eucalyptus urograndis trees at 6 years of age in a crop-livestock-forest integration system (ILPF). The study also aimed to calculate the use of nutrients in biomass conversion through the BUC and design different scenarios for the export of these nutrients through the harvest, in order to calculate the reduction in the demand for inputs.

\section{MATERIALS AND METHODS}

\section{Characterization of the study area}

The study was carried out in the municipality of Cachoeira Dourada in the south of the State of Goiás, GO, Brazil. The city is 240 kilometers from the capital Goiânia and at the following geographical coordinates: latitude 1829 ' 30 ' 'S, longitude 49 28' 30 " W, and altitude of 459 meters in relation to the average sea level. It is near and washed by the waters of the Paranaíba River and the Rio Meia Ponte (GUIMARÃES et al., 2016). According to Köppen and Geiger, the climate is classified as Aw. The average annual temperature is 
$24.8{ }^{\circ} \mathrm{C}$. It has an average annual rainfall of $1229 \mathrm{~mm}$, and August is the driest month with $4 \mathrm{~mm}$. Most precipitation falls in January, presenting an average of $246 \mathrm{~mm}$.

The study area has soils that are typical of the tropical regions. It very weathered due to the aggressiveness of the active factors of soil formation and the intensity of the pedogenetic processes, as well as with low natural fertility (CABRAL, 2011). According to Assis et al. (2015) and Cabral et al. (2011), the predominant soil is classified as a Red Latosol with an "A" horizon, moderately and prominently of a very clayey texture. In small areas, Argisols, Nitosols, Gleissoles, and Neosols occur with pH varying from 4.3 to 6.2 .

The study area covers approximately 15 hectares, and there is a crop-livestock-forest integration system (ILPF). Two clones of six-year-old Eucalyptus grandis x Eucalyptus urophylla hybrids (Eucalyptus urograndis) were planted ( $3 \mathrm{~m} \times 2 \mathrm{~m}$ ) with Brachiaria brizantha (Urochloa brizantha Stapf.) grass in the spacing between the three triple lines. $14 \mathrm{~m}$ of pasture for the grazing of the animals were rotated with other areas, and there was stock of three heads per hectare, 1.4 AU.

\section{Above-ground Biomass}

The forest inventory was carried out, measuring all individuals in the forest livestock farming integration system, with the measurement of the diameter at chest height (DBH: diameter at 1.30 meters in height in relation to the ground level). After the census, the diametric distribution was performed in four classes. For sampling the tree components, classes were used to define the individuals that were sampled, these individuals being the trees corresponding to the upper and lower limits and the central measure of the class, thus totaling three trees per class, and 12 trees felled to measure biomass.

The estimate of above-ground eucalyptus biomass was calculated in a study developed by Lemos Júnior et al. (2016), where the following results were obtained in Table 1.

Table 1: Eucalyptus urograndis above-ground biomass at 6 years of age (2015).

\begin{tabular}{ll}
\hline Component & ILPF $\left(\mathrm{kg} \mathrm{ha}^{-1}\right)$ \\
\hline Bark & 11.730 \\
\hline Leaves & 4.370 \\
\hline Branches & 14.000 \\
\hline Wood & 114.260 \\
\hline Total & 144.360 \\
\hline
\end{tabular}

\section{Nutrient concentration and stock of tree components}

For the determination of the nutritional stock, after the samples were dried, they were milled using Willey blades with a 20-mesh sieve. Analysis of macronutrients N, P, K, Ca, Mg, and S and micronutrients B, $\mathrm{Cu}, \mathrm{Fe}, \mathrm{Mn}$, and Zn were carried out at the Forest Ecology Laboratory of the Department of Forestry Sciences of the Federal University of Santa Maria/RS, following the Methodology suggested by Tedesco et al. (1995) and Miyazawa et al. (1999). The procedures are described in table 2 below. 
Table 2: Description of the analytical procedures used in the determination of nutrients in samples of plant tissue.

\begin{tabular}{llll}
\hline Nutrients & Digestion & Method & Wavelength $(\mathrm{nm})$ \\
\hline $\mathrm{N}$ & \multicolumn{1}{c}{ Sulfuric } & Kjeldahl & - \\
\cline { 2 - 4 } & $\left(\mathrm{H}_{2} \mathrm{SO}_{4}+\mathrm{H}_{2} \mathrm{O}_{2}\right)$ & & 422.67 \\
$\mathrm{Ca}$ & & Atomic absorption spectroscopy & 285.21 \\
$\mathrm{Mg}$ & & Esp & 324.75 \\
$\mathrm{Cu}$ & & 248.33 \\
$\mathrm{Fe}$ & Nitric-perchloric & & 279.48 \\
$\mathrm{Mn}$ & $\left(\mathrm{HNO}_{3}+\mathrm{HClO}_{4}\right)$ & & 213.86 \\
$\mathrm{nn}$ & {$[3: 1]$} & Flame photometry & - \\
$\mathrm{K}$ & & Spectrophotometry & 660.00 \\
$\mathrm{P}$ & & Turbidimetry & 420.00 \\
$\mathrm{~S}$ & & Spectrophotometry & 460.00 \\
\hline $\mathrm{B}$ & & & \\
\hline
\end{tabular}

\section{Analysis of the main components of nutritional contents}

A principal components analysis (PCA) was carried out with a covariance matrix to assess the nutritional contents of eucalyptus biomass compartments and also nutritional stock, and for the following parameters nutrition content (nitrogen $(\mathrm{N})$, phosphorous $(\mathrm{P})$, potassium $(\mathrm{K})$, calcium $(\mathrm{Ca})$, magnesium $(\mathrm{Mg})$, sulfur $(\mathrm{S})$, sodium $(\mathrm{Na})$, copper $(\mathrm{Cu})$, iron $(\mathrm{Fe})$, manganese $(\mathrm{Mn})$, zinc $(\mathrm{Zn})$, cobalt $(\mathrm{Co})$ and molybdenum (Mo) with regards to the different litter compartment: leaves, branches, bark and wood (GUIMARÃES et al., 2016). All analyses were conducted considering a significance level of $95 \%$. The nutritional contents of each eucalyptus biomass compartment were also evaluated using PERMANOVA with a 95\% significance level.

To compare the effect of the diameter of the trees in relation to the different nutritional contents of the eucalyptus compartments, multiple regressions were performed, observing contents, compartment and diameter at breast height, at the $95 \%$ significance level. The nutrients that were influenced by the diameter distribution were presented in a scatter plot to verify the effect of the regression.

\section{Biological Utilization Coefficient (BUC)}

The Biological Utilization Coefficient (BUC) of nutrients was obtained by the ratio between the amount of biomass and nutrients, both with the same unit (VIEIRA et al., 2015). This parameter corresponds to the conversion rate of nutrients into biomass.

\section{Nutrition export scenarios}

The harvesting of trees promotes consequent export of nutrients from the plantation. Considering the different harvest intensities of total biomass above the soil, wood + bark, or wood, nutritional export scenarios were calculated. After obtaining these data, the fiscal values that can be saved were estimated, considering the harvest residues at the site.

\section{RESULTS}

\section{Nutrient concentration and stock of above-ground biomass}

It is noted that the highest concentrations of all the macronutrients are present in the wood component with the exception of $\mathrm{Ca}$ that presented higher concentration in the bark compartment. When 
analyzing the concentration gradient of the nutrients in the compartments studied, it was observed that the bark and twig fractions follow the same pattern: $\mathrm{Ca}>\mathrm{K}>\mathrm{N}>\mathrm{Mg}>\mathrm{P}>\mathrm{S}$. Table 3 presents the average values for nutrient concentrations of the different Eucalyptus biomasses in the integrated system. In the Table 4 presents the concentrations of macro and micronutrients, respectively.

Table 3: Mean values of nutrients found in the compartments of Eucalyptus urograndis at 6 years of age

\begin{tabular}{lllllll|lllll}
\hline \multirow{2}{*}{ Compartments } & $\mathrm{N}$ & $\mathrm{P}$ & $\mathrm{K}$ & $\mathrm{Ca}$ & $\mathrm{Mg}$ & $\mathrm{S}$ & $\mathrm{B}$ & $\mathrm{Cu}$ & $\mathrm{Fe}$ & $\mathrm{Mn}$ & $\mathrm{Zn}$ \\
\cline { 2 - 34 } & $\mathrm{g} \mathrm{kg}^{-1}$ & & & & & & $\mathrm{mg} \mathrm{kg}^{-1}$ & & & & \\
\hline Leaves & 15,23 & 1,60 & 8,54 & 8,52 & 3,41 & 0,86 & 35,75 & 10,92 & 555,82 & 316,30 & 9,66 \\
Branches & 4,82 & 1,09 & 6,81 & 7,83 & 2,60 & 0,31 & 8,84 & 4,37 & 294,04 & 153,91 & 6,83 \\
Bark & 4,11 & 1,19 & 9,12 & 13,70 & 2,57 & 0,29 & 12,74 & 5,95 & 518,72 & 175,54 & 6,29 \\
\hline Wood & 1,63 & 0,21 & 2,06 & 0,61 & 0,36 & 0,12 & 1,56 & 2,54 & 16,32 & 40,35 & 2,79 \\
\hline
\end{tabular}

Table 4: Stock of macronutrients in the different compartments of the biomass of Eucalyptus urograndis at 6 years of age

\begin{tabular}{lllllll}
\hline \multirow{2}{*}{ Compartments } & $\mathrm{N}$ & $\mathrm{P}$ & $\mathrm{K}$ & $\mathrm{Ca}$ & $\mathrm{Mg}$ & $\mathrm{S}$ \\
\cline { 2 - 7 } Leaves & $\mathrm{kg} \mathrm{ha}^{-1}$ & & & & & \\
\cline { 2 - 7 } Branches & 67.013 & 6.992 & 37.855 & 36.047 & 14.901 & 3.687 \\
Bark & 66.972 & 14.752 & 92.172 & 117.337 & 38.395 & 4.270 \\
\hline Wood & 47.255 & 13.539 & 106.977 & 172.866 & 34.067 & 3.451 \\
\hline
\end{tabular}

This is mainly due to the large accumulation of biomass in the bark of trees, especially in eucalyptus plantations. This plant, in percentage terms, have more than four times the amount of this component in relation to natural forest trees.

For the leaf compartment of the plant, the nutritional gradient followed the order: $\mathrm{N}>\mathrm{K}>\mathrm{Ca}>\mathrm{Mg}>$ $\mathrm{P}>\mathrm{S}$. The wood component followed almost the same sequence: $\mathrm{K}>\mathrm{N}>\mathrm{Ca}>\mathrm{Mg}>\mathrm{P}>\mathrm{S}$. The rank order of nutrient storage in the compartments, considering the average values, presented the following order: Wood> Bark> Branches> Leaves.

The amount of nutrients is a consequence of their concentrations and the production of biomass. And the highest concentrations of nutrients in trees are in the canopy. Table 5 presents the number of micronutrients stored according to the amount of above-ground biomass.

Table 5: Micronutrient stock in different biomass compartments of Eucalyptus urograndis at 5 years old

\begin{tabular}{llllll}
\hline \multirow{2}{*}{ Compartments } & $\mathrm{B}$ & $\mathrm{Cu}$ & $\mathrm{Fe}$ & $\mathrm{Mn}$ & $\mathrm{Zn}$ \\
\cline { 2 - 6 } Leaves & $\mathrm{kg} \mathrm{ha}^{-1}$ & & & & \\
\cline { 2 - 6 } Branches & 0,151 & 0,051 & 2,814 & 1,388 & 0,041 \\
Bark & 0,156 & 0,060 & 3,977 & 2,444 & 0,094 \\
\hline Wood & 0,143 & 0,066 & 7,783 & 2,504 & 0,082 \\
\hline
\end{tabular}

In relation to the micronutrients, a great predominance of the iron element was observed. For only the wood component, the $\mathrm{Mn}$ was higher than the Fe concentration. The micronutrient concentration gradient was as follows: Leaves: $\mathrm{Fe}>\mathrm{Mn}>\mathrm{B}>\mathrm{Cu}>\mathrm{Zn}$; Branches: Fe> Mn> B> Zn>Cu; Bark: Fe $>\mathrm{Mn}>\mathrm{B}>\mathrm{Zn}>$ Cu; Wood: $\mathrm{Mn}>\mathrm{Fe}>\mathrm{Zn}>\mathrm{Cu}>\mathrm{B}$.

In the multivariate analysis, in relation to the nutritional contents of eucalyptus biomass, the leaf, bark and branch components were the most abundant in macro and micronutrients. Leaves had higher levels of $\mathrm{B}, \mathrm{Cu}, \mathrm{S}$ and $\mathrm{N}$. Bark and branch, higher levels of $\mathrm{Ca}, \mathrm{K}, \mathrm{Mg}, \mathrm{Fe}, \mathrm{P}, \mathrm{Mn}$ and $\mathrm{Zn}$. The trunk/wood had the 
lowest levels in relation to most nutrients. The biomass components showed significant differences in nutritional composition, with leaf, bark, twig and trunk being different from each other, with only similar leaf and bark (Permanova $\mathrm{R}=0.83, \mathrm{p}=0.0001$ ) (Figures 1 and 2 ).

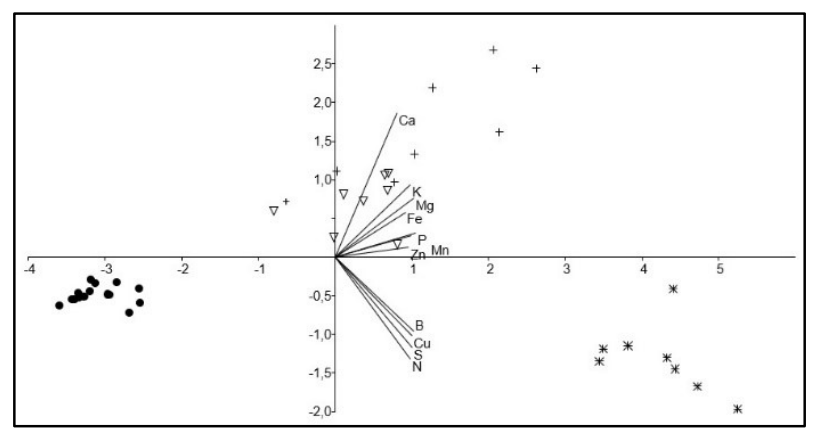

Figure 1: Analysis of the main components of the nutritional contents of eucalyptus biomass (Asterisk Leaf, Cross - Bark, Inverted triangle - Branches, Black circle - wood) (PC1-76,86\% e PC2 - 11,85\%).

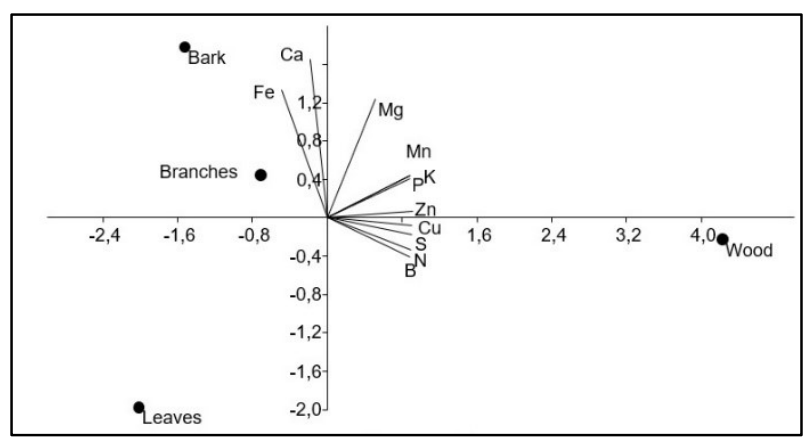

Figure 2: Analysis of the main components of the total nutrient values (nutritional stock) of eucalyptus (PC1 75,03\%, PC2- 22,21\%).

When the nutritional aspect is extrapolated to the biomass value per kilo, the values of the eucalyptus nutritional stock are defined. In this case, as the values of wood biomass are higher than other components of biomass, the nutritional aspect is also concentrated in this compartment, even if it is the one with the lowest nutritional content.
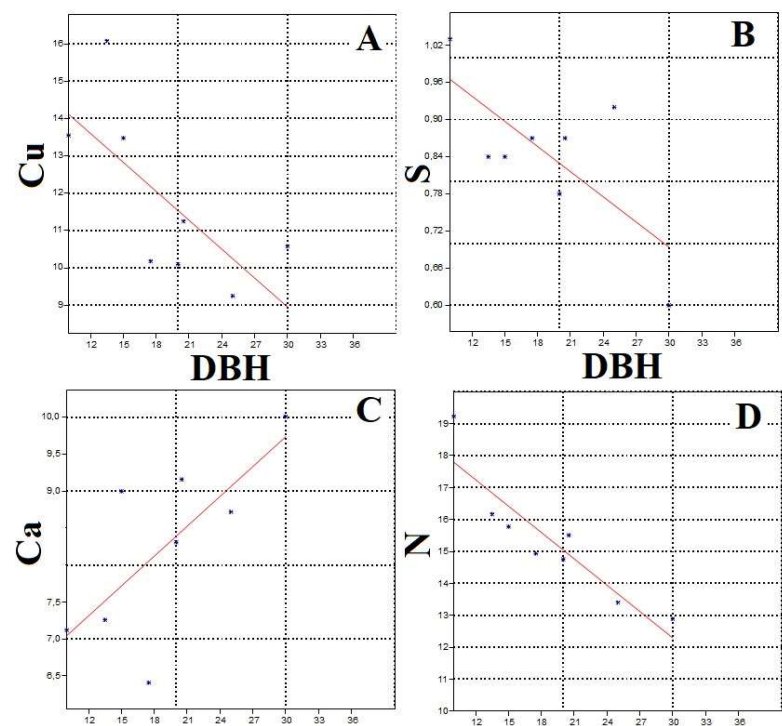

DBH

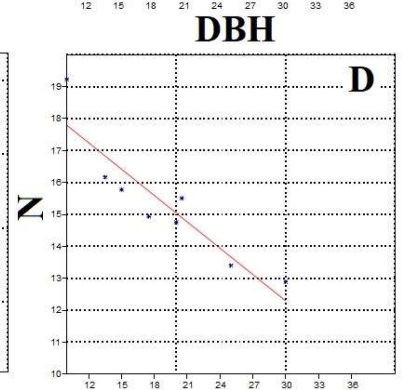

DBH

Figure 3: Distribution of nutritional levels of leaves (A Copper, B - Sulfur, C - Calcium and D - Nitrogen) in different diameters of the eucalyptus (only elements that showed statistical significance above $95 \%$ are shown in the graphs).

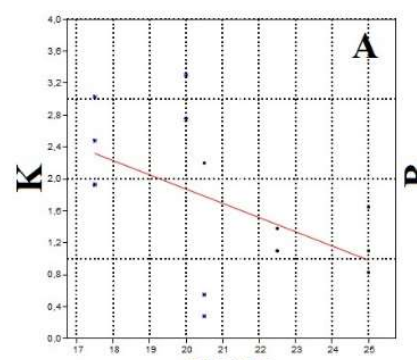

DBH
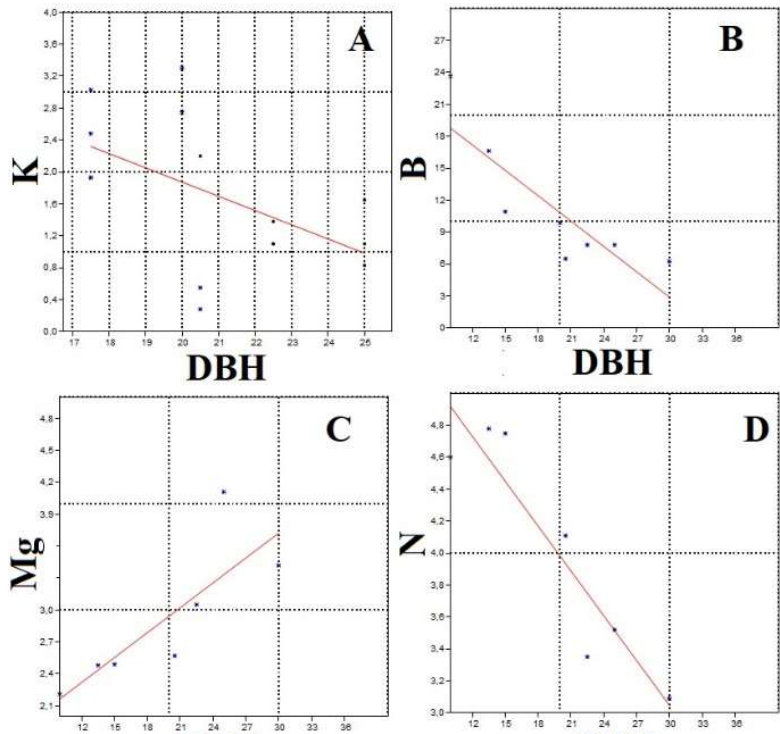

DBH

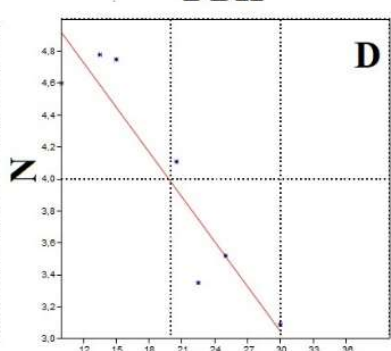

DBH

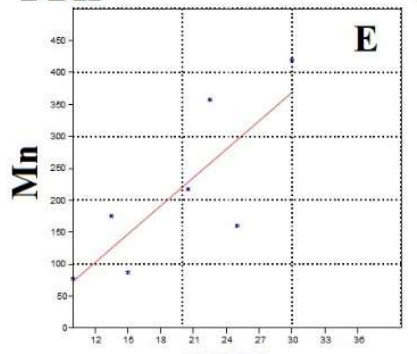

DBH

Figure 4: Distribution of nutritional contents of $A$ Nitrogen in the wood, B - Boron in the branches, $C$ Magnesium, D - Nitrogen, and E - Manganese in the eucalyptus bark (only elements that showed statistical significance above 95 are shown in the graphs \%). 
The relationships of the nutritional contents of each component were different in relation to the diameters of eucalyptus. For the leaf component, $\mathrm{Cu}, \mathrm{S}$ and $\mathrm{N}$ showed a negative relationship in relation to the increase in the diameter of the tree, the larger the diameter, the lower the content of these elements in the leaf. As for $\mathrm{Ca}$, the relationship was inverse, the larger the diameter, the higher the calcium content in the leaves. For the other nutritional elements, there were no changes in the different diameters, as can be seen in figures 3 and 4 .

The nutritional levels of nitrogen in the wood reduce in relation to the increase in the diameter of the eucalyptus. Boron also follows the same decreasing pattern in branches. For the bark, both magnesium and manganese increase with increasing diameter, but nitrogen levels decrease.

\section{Biological Utilization Coefficient (BUC)}

Among the components present, the wood compartment presented the highest conversion rates of nutrients into biomass for all macronutrients and micronutrients. In relation to the decline of this conversion rate, the following orders was determined: $\mathrm{S}>\mathrm{P}>\mathrm{Mg}>\mathrm{Ca}>\mathrm{N}>\mathrm{K}$ for macronutrients and $\mathrm{B}>\mathrm{Cu}>\mathrm{Zn}>\mathrm{Fe}>\mathrm{Mn}$ for micronutrients. Table 6 presents the values of the BUC rates for the macro and micronutrients of the components of the eucalyptus trees.

Table 6: Biological Utilization Coefficient (BUC) for the different components of the biomass of Eucalyptus urograndis at 6 years of age

\begin{tabular}{l|llllll}
\hline Macronutrients & \multicolumn{7}{l}{} \\
\hline Compartments & $\mathrm{N}$ & $\mathrm{P}$ & $\mathrm{K}$ & $\mathrm{Ca}$ & $\mathrm{Mg}$ & $\mathrm{S}$ \\
Leaves & 65.2103 & 625 & 115.4401 & 121.2305 & 293.2551 & 1185.185 \\
Branches & 209.041 & 948.9917 & 151.8891 & 119.3139 & 364.6308 & 3278.689 \\
Bark & 248.227 & 866.3366 & 109.6491 & 67.85576 & 344.3187 & 3398.058 \\
\hline Wood & 563.9118 & 4151.829 & 475.1028 & 1501.328 & 2924.634 & 7500.361 \\
\hline Micronutrients & \multicolumn{7}{l}{} & & & & \\
\hline Compartments & $\mathrm{B}$ & $\mathrm{Cu}$ & $\mathrm{Fe}$ & $\mathrm{Mn}$ & 104547.8 \\
Leaves & 28853.78 & 84682.97 & 1552.714 & 3146.831 & 148093.3 \\
Branches & 89445.44 & 231749.7 & 3520.197 & 5727.295 & 141614.4 \\
Bark & 81833.06 & 177574.8 & 1507.016 & 4683.841 & 331421.3 \\
\hline Wood & 628930.8 & 401234.6 & 58446.67 & 24179.75 & & \\
\hline
\end{tabular}

In relation to micronutrient utilization efficiency, copper was the most efficiently used nutrient in all components of the biomass, followed by $\mathrm{Zn}$, Fe, and Mn. In the present study, Cu had the highest efficiency in the branches and bark components. For the leaves, Zn was the most efficient, and in the wood, B had the greatest efficiency.

\section{Nutritional export scenarios}

Thus, the nutrient export scenarios, described in Table 7, contain the values in $\mathrm{kg} \mathrm{ha}^{-1}$ and consider what would be left in the area as plant material that is capable of returning nutrients to the system.

Scenarios were designed to demonstrate how nutrients would be returned to the soil if they were removed from the study area: whole trees (above ground biomass), only wood + bark, and only wood. The percentage of this nutrient quantity was also represented, where the whole tree variable was considered as $100 \%$ of the nutrients removed. 
Table 7: Macro and micronutrients export scenario in $\mathrm{kg} \mathrm{ha}^{-1}$ of Eucalyptus urograndis at 6 years of age

\begin{tabular}{|c|c|c|c|}
\hline Nutrients & Whole Tree & Wood + Bark & Wood \\
\hline \multirow{2}{*}{ Total Biomass } & \multicolumn{3}{|l|}{ kg ha-1 } \\
\hline & 144.360 & $125.990(87.27 \%)$ & $114.260(79.15 \%)$ \\
\hline $\mathrm{N}$ & 383.862 & 249.875 (65.09\%) & \begin{tabular}{|l|l|}
$202.620(52.78 \%)$ \\
\end{tabular} \\
\hline $\mathrm{P}$ & 62.805 & $41.050(65.36 \%)$ & \begin{tabular}{|l|}
$27.520(43.82 \%)$ \\
\end{tabular} \\
\hline $\mathrm{K}$ & 477.501 & $347.460(72.76 \%)$ & 240.495 (50.36\%) \\
\hline $\mathrm{Ca}$ & 402.357 & 248.960 (61.87\%) & \begin{tabular}{|l}
76.106 (18.91\%) \\
\end{tabular} \\
\hline $\mathrm{Mg}$ & 126.432 & $73.120(57.74 \%)$ & $39.068(30.90 \%)$ \\
\hline $\mathrm{S}$ & 26.643 & $18.680(70.11 \%)$ & \begin{tabular}{|l|}
$15.234(57.18 \%)$ \\
\end{tabular} \\
\hline $\mathrm{B}$ & 0.633 & $0.325(51.34 \%)$ & $0.182(28.75 \%)$ \\
\hline $\mathrm{Cu}$ & 0.463 & $0.351(75.81 \%)$ & $0.285(61.55 \%)$ \\
\hline $\mathrm{Fe}$ & 16.530 & $9.739(58.92 \%)$ & $1.955(11.82 \%)$ \\
\hline $\mathrm{Mn}$ & 11.063 & $7.230(65.35 \%)$ & $4.725(42.71 \%)$ \\
\hline $\mathrm{Zn}$ & 0.564 & $0.428(75.88 \%)$ & $0.345(61.17 \%)$ \\
\hline
\end{tabular}

It is noted that the macronutrients $\mathrm{K}, \mathrm{Ca}$, and $\mathrm{N}$ and micronutrients $\mathrm{S}, \mathrm{Fe}$, and $\mathrm{Mn}$ were the elements that suffered significant removal from the plantation when the whole tree was removed. When the scenario is changed and only wood + bark is removed, $13.73 \%$ of the biomass remains in the field. This leaves a total of $34.91 \% \mathrm{~N}\left(133.125 \mathrm{~kg} \mathrm{ha}^{-1}\right), 34.91 \%$ of $\mathrm{P}\left(21.755 \mathrm{~kg} \mathrm{ha}^{-1}\right)$, and $27.24 \%$ of $\mathrm{K}\left(130.041 \mathrm{~kg} \mathrm{ha}^{-1}\right)$ if only considering the macronutrients that are most used in agriculture. It was the micronutrients $\mathrm{S}, \mathrm{Cu}$, and $\mathrm{Zn}$ that were the most removed from the system.

When considering more conservative biomass harvesting, leaving the rest of the plant in the system further reduces the amount of nutrients being exported. It presented a reduction of $20.85 \%$ of exported biomass, which resulted in a reduction of $47.22 \%$ of $\mathrm{N}\left(181.242 \mathrm{~kg} \mathrm{ha}^{-1}\right), 56.18 \%$ of $\mathrm{P}\left(35.285 \mathrm{~kg} \mathrm{ha}^{-1}\right)$. and $49.64 \%$ of $\mathrm{K}\left(237.006 \mathrm{~kg} \mathrm{ha}^{-1}\right)$. Ca was the macronutrient that had more significant value when the scenario exports only wood, where it presented a reduction of $81.09 \%$ of $\mathrm{Ca}$ and represented $326.251 \mathrm{~kg} \mathrm{ha}^{-1}$. Cu, $\mathrm{Zn}$, and $\mathrm{S}$ were the micronutrients with higher contents exported when only the wood was removed from the site, and Fe and B were the elements that had the greatest reduction in the latter scenario.

From the economic point of view, the revenue generated from forest residues can be considerable. The weighting of the export scenarios was done according to the following fertilizers from a fertilizer company in the state of Goiás, as presented in Table 8. For the purposes of calculation, the cost of mechanized harvesting operation was not considered, since this practice varies according to the region and the size of the area to be harvested.

Table 8: Mineral fertilizers used as basis for the calculation of nutrient export scenarios.

\begin{tabular}{lllll}
\hline Fertilizer & Composition & Unit & Value (R\$) & Value (US\$) * \\
\hline Super Simple & $18 \%$ of $\mathrm{P}_{2} \mathrm{O}_{5}$ & sack of $50 \mathrm{~kg}$ & 77,00 & 20,48 \\
MAP purified & $61 \%$ of $\mathrm{P}_{2} \mathrm{O}_{5}$ & sack of $25 \mathrm{~kg}$ & 100,00 & 26,59 \\
MAP & $52 \%$ of $\mathrm{P}_{2} \mathrm{O}_{5}$ & sack of $25 \mathrm{~kg}$ & 124,00 & 32,98 \\
Potassium chloride & $60 \%$ of $\mathrm{K}_{2} \mathrm{O}$ & sack of $50 \mathrm{~kg}$ & 110,00 & 29,25 \\
Urea & $45 \%$ of $\mathrm{N}$ & sack of $50 \mathrm{~kg}$ & 115,00 & 30,58 \\
\hline
\end{tabular}

*Dollar in October of 2018: 3,76 \$; converting Real to Dollar: 1 US\$ = 3,76 R\$.

As a result, the following possible savings were generated in reais $(R \$)$ per $\mathrm{ha}^{-1}$ for the agricultural producer, as shown in Table 9. 
Table 9: Economies related to nutrient export scenarios by $\mathrm{ha}^{-1}$, according to the harvest intensity of Eucalyptus urograndis of 6 years.

\begin{tabular}{llll}
\hline Wood + Bark & Material Saved & Resources Saved (R\$) & Resources Saved (US\$) * \\
Fertilizer & 3 sacks & 353,50 & 94,01 \\
Super Simple & 2 sacks & 200,00 & 53,19 \\
MAP purified & 2 sacks & 248,00 & 65,96 \\
MAP & 5 sacks & 550,00 & 146,27 \\
Potassium Chloride & 6 sacks & 650,00 & 172,87 \\
Urea & & & \\
\hline Wood & Material Saved & Resources Saved (R\$) & Resources Saved (US\$) * \\
Fertilizer & 4 sacks & 310,00 & 82,45 \\
Super Simple & 3 sacks & 300,00 & 79,79 \\
MAP purified & 3 sacks & 372,00 & 98,93 \\
MAP & 8 sacks & 880,00 & 234,04 \\
Potassium Chloride & 8 sacks & 920,00 & 244,68 \\
Urea & P &
\end{tabular}

*Dollar in October of 2018: 3,76 \$; converting Real to Dollar: 1 US\$ = 3,76 R\$.

\section{DISCUSSION}

Our results show that the components of eucalyptus are rich in nutrients, with different levels in the different structures of the plant. Among the compartments of the plant, the leaves can be considered the most nutritionally rich in comparison to other biomasses. In any case, branches and barks are also relevant, especially due to the amount of biomass that can be deposited in the soil, increasing the levels of carbon directly linked to biomass.

For Brun et al. (2010), Ca is a practically immobile element in the plant phloem, which could explain its high concentration in the bark fraction, as well as the fact that the element is a structural component and is part of the middle lamella of the cell membrane.

Salvador et al. (2016) found similar results to the present study, where the eucalyptus of 6.7 years had the highest concentrations of Ca in the bark of the trees. According to Drumond et al. (1997) in their work with different forest covers, calcium was the nutrient with greater accumulation in the tree bark of the forests planted when compared to natural forests. This fact reaffirms the suggestion to carry out the debarking of the eucalyptus in the explored area.

When studying the nutritional status of Eucalyptus saligna at different ages, Salvador et al. (2016) concluded that at 5.5 and 6.7 years of age, trees presented $\mathrm{N}$ and $\mathrm{K}$ as the elements with greater concentration in the leaves, which is corroborated by the present work. However, the authors found high concentrations of $\mathrm{P}$ also, which did not occur in this work.

Witschoreck et al. (2015), studying the nutritional status of eucalyptus trees (Eucalyptus saligna) at different ages, concluded that with average values of nutrient stocks, their accumulation follows the following sequence: wood $>$ root $>$ leaf $>$ bark $>$ twig. This sequence was not the same as that obtained in this present study, where the leaf fraction was the one that accumulated less nutrients. Also, the root compartment was not analyzed. The greatest amount of biomass is found in the trunk (wood + bark), which is the part that is normally exploited (CALDEIRA et al., 2001; VIEIRA et al., 2011).

The distribution of nutrients generally differs from the observed biomass pattern, which is due to the great difference in the concentration of nutrients between the components (REIS et al., 1990). The main 
example of this is the leaves, considered the plant's metabolic center, which is the component with the highest concentration for most nutrients (MARSCHNER, 1995). It also generally presents the lowest accumulation of biomass, especially in adult stands (WITSCHORECK et al., 2015).

According to Witschoreck et al. (2015), the BUC demonstrates how many units of biomass is formed per unit of nutrient, and a higher value suggests a more efficient rate of nutrient conversion into biomass. In practical terms, this coefficient should be as large as possible, thus less nutrient per unit of biomass will be uptaken.

When analyzing the BUC for trunk mass production of three eucalyptus clones at 84 months of age, Rosim et al. (2016) showed a decrease in the order: $\mathrm{P}>\mathrm{S}>\mathrm{Mg}>\mathrm{Ca}>\mathrm{N}>\mathrm{K}$. This result, similar to the present study, differed only in the position between $\mathrm{S}$ and $\mathrm{P}$. The author reports that this difference in the decrease of the elements may be related to the age of the trees and to the difference of the soil fertility, among other factors. In addition, another factor that contributes to the increase of the nutrient utilization efficiency is the reduction of biomass allocated to the tree canopy, whose components are rich in nutrients, and increase of biomass allocated to wood, a component with lower nutrient contents.

Vieira et al. (2015) pointed out that different 10-year-old eucalyptus species had wood that presented the highest BUC values, which is very desirable and of great interest to forestry, except for Fe. According to the authors, the coefficient of utilization of the wood macronutrients decreased in the order: $\mathrm{P}>\mathrm{S}>\mathrm{Mg}>\mathrm{Ca}>\mathrm{N}>\mathrm{K}$, which is the same sequence found by Rosim et al. (2016). The use of $\mathrm{S}$ and $\mathrm{P}$ differed from the current study; however, the results of both studies are similar.

The high efficiency presented by a species in the use of nutrients implies that it has a lower nutritional requirement. It is therefore a parameter of great utility in the selection of species to be used in the plantations, especially in soils of low natural fertility (SILVA et al., 1983).

Salvador et al. (2016) argue that in many cases, farm waste that consists of leaves, branches, and bark of trees for energy production in companies, is used in addition to wood. One of the main objectives of forestry companies is to significantly increase the productivity of their forests. They can both expand their planting areas and increase the production of raw material in order to meet the needs of the market. This practice interferes with the cycling of nutrients and the maintenance of the productive capacity of the site, since the export of nutrients is intensified as the biomass removed from the area increases.

According to Schumacher et al. (2013), the harvesting of only the trunk wood is the most conservative modality of biomass utilization, and it is the ideal condition for reduction of the nutritional impact of this activity. The same study reported that nutrient exports in Pinus taeda at 17 years reflected an increase of $11.8 \%$ in the biomass, in addition to preventing the return of $11.8 \%$ of $\mathrm{Mn}$ and $186.2 \%$ of Fe to the system.

However, Vieira et al. (2015) observed that when using this wood + bark harvest intensity, the removal of nutrients would reach a percentage of $71 \%$ for $\mathrm{K} ; 66 \%$ for $\mathrm{Ca}$ and $\mathrm{Zn} ; 63 \%$ for $\mathrm{P} ; 61 \%$ for $\mathrm{Mg} ; 57 \%$ for $\mathrm{S} ; 47 \%$ for the $\mathrm{N}$; and $45 \%$ for the $\mathrm{Mn}$. In terms of comparison, the same authors reported that fertilizers were not applied to simply only remove the wood component from the harvest and reached: $762.64 \mathrm{~kg} \mathrm{ha}^{-1}$ of urea $(45 \% \mathrm{~N}), 153.08 \mathrm{~kg} \mathrm{ha}^{-1}$ of triple superphosphate $\left(46 \%\right.$ of $\left.\mathrm{P}_{2} \mathrm{O}_{5}\right)$, and $466.30 \mathrm{~kg} \mathrm{ha}^{-1}$ of potassium 
chloride $\left(60 \%\right.$ of $\left.\mathrm{K}_{2} \mathrm{O}\right)$.

The harvesting method used and postharvest handling affect the degree of disturbance in the nutrient cycling for the site. Possibly, the main issue is not how much of nutrients is removed but, rather, how the amount removed compares with the amount available in the soil for new cropping cycles after harvest (KOZLOWSKI et al., 1991). Studies on calculations made with mechanized harvesting are scarce, even when it comes to estimates. Thus, for precise values on the practice of harvesting, expenses generated and which could be saved with forest residues, further studies must be carried out.

Studies analyzing the nutritional impact of the export of nutrients by the harvest are of paramount importance in order to maintain the productive capacity of the site, in addition to being possible to seek alternatives that minimize the contribution of resources for future planting cycles.

\section{CONCLUSIONS}

In general, the nutrient content in the leaves is significantly higher than in the other biomass compartments above the ground, as this fraction being an important pathway within the nutrient cycling.

The wood, even presenting lower levels of nutrients, is more efficient in their use. The choice of the most efficient forest harvesting strategy is decisive to guarantee the maintenance of nutrients for the site. With a greater amount of biomass exported, there is greater nutritional export, which will jeopardize the establishment of future planting.

The highlight of the PCA was the different nutritional compositions within the structure of the plant, especially the leaf, which contained greater richness for the elements, but in the end with the total biomass the nutrients are even stored in the wood. The regressions revealed that with the development and structural change of the tree, the nutritional dynamics changes, according to the demand, and there may be more or less nutrients according to the need for a particular compartment.

\section{REFERENCES}

ASSIS, P. C. R.; STONE, L. F.; MEDEIROS, J. C.; MADARI, B. E.; OLIVEIRA, J. M.; WRUCK, F. J.. Atributos físicos do solo em sistemas de integração lavoura-pecuária-floresta. Revista Brasileira de Engenharia Agrícola e Ambiental- AGRIAMBI, v.19, n.4, 2015

BRUN, E. J.; BRUN, F. G. K.; CORRÊA, R. S.; VACCARO, S.; SCHUMACHER, M. V.. Dinâmica de micronutrientes na biomassa florestal em estágios sucessionais de Floresta Estacional Decidual, RS, Brasil. Scientia Florestalis, Piracicaba, v.38, n.86, p.307-318, 2010.

CABRAL, J. B. P.; BECEGATO, V. A.; FERNANDES, L. A.; SILVA, S. A.. Caracterização Sedimentológica dos Modelos Deposicionais do Reservatório de Cachoeira Dourada GO/MG. Geosul (UFSC), v.26, p.175-198, 2011.

CALDEIRA, M. V. W.; SCHUMACHER, M. V.; RONDON NETO, R. M.; WATZLAWICK, L. F.; SANTOS, E. M.. Quantificação da biomassa acima do solo de Acacia mearnsii De Wild., procedência Batemans Bay- Austrália. Ciência Florestal,
Santa Maria, v.11, n.2, p.79-91, 2001.

DRUMOND, M. A.; BARROS, N. F.; SOUZA, A. L.; SILVA, A. F. Distribuição de biomassa e de nutrientes em diferentes coberturas florestais e pastagem na região do Médio Rio Doce-MG. R. Árvore, v.21, p.187-199, 1997.

GONÇALVES, J. L. M.; ALVARES, C. A.; SOUZA, A. H. B. N.; ARTHUR JUNIOR, J. C.. Caracterização edafoclimática e manejo de solos das áreas com plantações de eucalipto. In: SCHUMACHER, M. V.; VIEIRA, M.. Silvicultura do eucalipto no Brasil. Santa Maria: UFSM Publishing, 2015. p.113-156.

GUIMARÃES, L. E.; SILVA NETO C. M.; CALIL, F. N.. Densidade de Fluxo de Fótons (DFF) em um sistema de Integração Lavoura-Pecuária-Floresta (ILPF). Revista Ecologia e Nutrição Florestal-ENFLO, v.4, n.1, p.10-18, 2016.

IBA. Indústria Brasileira de Árvores. Brazilian tree industry. Report: IBÁ, 2016. 
KOZLOWSKI, T. T.; KRAMER, P. J.; PALLARDY, S.. The physiological ecology of woody plants. Academic Press, 1991.

LAFETÁ, B. O.; SANTANA, R. C.; NOGUEIRA, G. S.; NEVES, J. C. L.; PENIDO, T. M. A.. Eficiência na utilização de macronutrients em eucalipto por método não-destrutivo estimado por redes neurais artificiais. Ciência Florestal, Santa Maria, v.28, n.2, p.613-623, 2018.

LEMOS JÚNIOR, J. E. M.; SILVA NETO, C. M.; SOUZA, K. R.; GUIMARÃES, L. E.; OLIVEIRA, F. D.; GONÇALVES, R. A.; MONTEIRO, M. M.; LIMA, N. L.; VENTUROLI, F.; CALIL, F. N.. Volumetric models for Eucalyptus grandis $x$ urophylla in a crop-livestock-forest integration (CLFI) system in the Brazilian cerrado. African Journal of Agricultural Research, v.11, n.15, p.1336-1343, 2016.

MARSCHNER, H.. Mineral nutrition of higher plants. 2 ed. London: Academic Press, 1995.

MIYAZAWA, M.; PAVAN, M. A.; MURAOKA, T.. Análises químicas de tecido vegetal. In: SILVA, F. C.. Manual de análises químicas de solos, plantas e fertilizantes. Brasília: Embrapa Comunicação para Transferência de Tecnologia, 1999. p.171-224.

REIS, M. G. F.; BARROS, N. F.. Ciclagem de nutrientes em plantios de eucalipto. In: BARROS, N. F.; NOVAIS, R. F.. Relação solo eucalipto. Viçosa: Folha de Viçosa, 1990. p.265302.

ROSIM, C. C.; HSING, T. Y.; PAULA, R. C.. Nutrient use efficiency in interspecific hybrids of eucalypt. Revista Ciência Agronômica, v.47, n.3, p.540-547, 2016.

SALVADOR, S. M.; SCHUMACHER, M. V.; VIEIRA, M.; STAHL, J.; CONSENSA, C. B.. Biomassa e estoque de nutrientes em plantios clonais de Eucalyptus saligna Smith. em diferentes idades. Scientia Forestalis, Piracicaba, v.44, n.110, p.311321, 2016. DOI:

http://dx.doi.org/10.18671/scifor.v44n110.04
SCHUMACHER, M. V.; WITSCHORECK, R.; CALIL, F. N.; LOPES, V. G.. Biomassa e nutrientes no corte raso de um povoamento de Pinus taeda L. de 27 anos de idade em cambará do sul - RS. Ciência Florestal, v.23, n.2, p.321-332, 2013. DOI: https://dx.doi.org/10.5902/198050989278

SILVA, H. D.; POGGIANI, F.; COELHO, L. C.. Biomassa, concentração e conteúdo de nutrientes em cinco espécies de Eucalyptus plantadas em solos de baixa fertilidade. Pesquisa Florestal Brasileira, v.6, p.9-25, 1983.

TEDESCO, M. J.; GIANELLO, C.; BISSANI, C. A.; BOHNEN, H.; VOLKWEISS, S. J.. Análise de solo, plantas e outros materiais. 2 ed. Porto Alegre: UFRGS, 1995.

VIEIRA, M.; SCHUMACHER, M.. Biomassa em monoespecíficos de Eucalipto e Acácia: negra e do milho em sistema agrossilvicultural. Cerne, Lavras, v.17, n.2, p.259265, 2011.

VIEIRA, M.; SCHUMACHER, M. V.; CALDEIRA, M. V. W.. Dinâmica de Decomposição e Nutrientes em Plantio de Eucalyptus urophylla $\times$ Eucalyptus globulus no Sul do Brasil. Floresta e Ambiente, Seropédica, v.20, n.3, p.351-360, 2013.

VIEIRA, M.; SCHUMACHER, M. V.; TRUBY, P.; ARAUJO, E. F.. Implicações nutricionais com base em diferentes intensidades de colheita da biomassa de Eucalyptus urophylla x Eucalyptus globulus. Ciencia Rural, v.45, n.3, p.432-439, 2015. DOI: http://dx.doi.org/10.1590/0103$\underline{8478 \mathrm{cr} 20120367}$

VOGEL, H. L. M.; SCHUMACHER, M. V.; TRÜBY, P.. Biomassa e macronutrientes de uma Floresta Estacional Decidual em Itaara, RS, Brasil. Revista Árvore, v.37, n.1, p.99-105, 2013.

WITSCHORECK, R.; SCHUMACHER, M. V.. Locação de nutrientes em povoamentos de Eucalyptus saligna Sm. na região de Guaíba, Rio Grande do Sul. Cerne, v.21, n.4, p.625$632,2015$.

A CBPC - Companhia Brasileira de Produção Científica (CNPJ: 11.221.422/0001-03) detém os direitos materiais desta publicação. Os direitos referem-se à publicação do trabalho em qualquer parte do mundo, incluindo os direitos às renovações, expansões e disseminações da contribuição, bem como outros direitos subsidiários. Todos os trabalhos publicados eletronicamente poderão posteriormente ser publicados em coletâneas impressas sob coordenação da Sustenere Publishing, da Companhia Brasileira de Produção Científica e seus parceiros autorizados. Os (as) autores (as) preservam os direitos autorais, mas não têm permissão para a publicação da contribuição em outro meio, impresso ou digital, em português ou em tradução. 